\title{
International Trading Wars and Governance: The Effect of COVID-19
}

\author{
Fassory Sangaré \\ Faculty of Economics, University of Social Sciences and Management, Bamako, Mali
}

\section{Email address}

bayinisang@yahoo.fr

\section{To cite this article:}

Fassory Sangaré. International Trading Wars and Governance: The Effect of COVID-19 Journal of Business and Economic Development. Vol. 6, No. 2, 2021, pp. 73-81. doi: 10.11648/j.jbed.20210602.13

Received: April 8, 2021; Accepted: May 3, 2021; Published: May 21, 2021

\begin{abstract}
Left from China in December 2019, the COVID-19 became a pandemic causing many casualties on all continents in addition to its devastating effects on the running of the world economy. The palpable impacts of the economic crisis that erupted in the early hours of 2020 have been exceptional since the Second World War. In this straight line, we can enumerate the fall in world production, the recession of the French economy following a slowdown over one semester, the rise in unemployment in the United States (14.7\%) in May 2020, a number of countries affected by the crisis and the debt service moratorium called for by African countries. This situation has necessitated the release of huge sums of money by central bankers and governments to support economic sectors. This COVID risks complicating global governance, which is already undermined by the recurrence of trade wars between Nation-States. The objective of this paper was therefore to reflect on the consequences of this crisis on world trade in particular, the trade tensions, repressions and retaliation that the pandemic will provoke. The study reviewed the theories of economic protectionism, the arguments of geopolitics and the analysis of World Trade Organization data. This descriptive approach reveals the causes of trade wars and hightlights the protagonists and the resulting negative consequences on the volume of trade in terms of supply reduction and price increases due to protectionist trends. Overall, it appears in this work that the advent of the COVID accelerates the global decline in addition to its health victims all over the world. Basically, an improvement in global governance is recommended to mitigate the devasting effects of the COVID-19 pandemic.
\end{abstract}

Keywords: Conflicts, Trade Wars, WTO, COVID, Governance

\section{Introduction}

All analysts are expecting an unprecedented recession [2] since the Second World War as the shock of the pandemic and the containment measures induce a dramatic drop in production. In some countries, this reduction has been in addition to the negative impacts of the 2008 financial crisis, and the deterioration of public finance management like in Greece. A $15 \%$ drop in gross domestic product is even envisaged in OECD countries. So the real demand of an emerging economy is not able to compensate for the fall in demand from the best economies in the world, which explains the collapse in the prices of raw materials (oil, minerals) with the exception of the yellow metal, which remains the only true safe haven on a global scale until proven otherwise. Also, the sudden cessation of production and global commercial activities has led to a liquidity crisis for both companies and people suffering from unemployment because they are de facto unable to keep their commitments.

The developed states are now obliged to financially support "via subsidies and loans at reduced rates or no ", some sectors to take off again. This is the case of aeronautics, tourism and industry in France to illustrate.

In addition, to advance liquidity and put in place mechanisms to reduce or postpone tax burdens for businesses and households, States must continue to help the financial sector impacted by the stock market fall and by the multiplication of debts.

\section{Review of Literature}

A few central questions form the backbone of this brief review. The authors discussed the issue of covid from the 
health, economic and social point of view [7]. For example the World Bank explains that the loss in income could create approximately 350 million additional poor persons [20] in both lower-and upper middle-income countries. This is equivalent to an increase in the poverty rate by 2.3 percentage points compared to a no Covid-19 context.

Others address this crisis in terms of the impact of pandemic on migrant workers [21] in the informal and spinoff effects in their destination and home countries (Dramane Coulibaly, Mohamed Sharif Ahmed, Fatih Karanfil, Hind Kinani, Ana B. Moreno, Luc D. Omgba, Nhusha Vu, 2020, T20 Saudi Arabia think).

It is appropriate to point out that the meteoric rise in health and social assistance spending has paralleled the downward trend in tax revenues.

Particularly in Africa, the crisis has led to a fall in the prices of export products. Tourism has stopped in the same vein as international flights, also affecting exports which are vital for African economies (cotton for Mali, Coffee and Cocoa for Côte d'Ivoire for example).

Migrant remittances have been hit hard. They represent 5\% of Africa's Gross Domestic Product. The jaws effect characterized by higher spending and lower tax revenue is significant. Hence the economic logic which has led African States to demand a moratorium on the payment of public and private debt services. Basically, this moratorium has mobilized 20 billion dollars that enabled African governments to finance urgent spending on health and to take accompanying measures related to containment.

\section{Methodology}

It is based on WTO data [19], protectionism theories, anti competitive practices. These latest measures are exacerbated by anti COVID barriers such as the closure of borders, the quota of certain exports (Covid vaccines, face masks, nursing devices and others products).

If the pandemic persists, the World Trade Organization forecasts a real drop in the volume of world trade between $13 \%$ and $32 \%$ in 2020 .

Regarding the recovery of world trade at a normal pace, it is expected in 2021, but depends on the prospects of the pandemic and the effectiveness of political responses. Moreover, the table below provides an edifying light:

Table 1. Volume of trade in goods and real gross domestic product 2018-2021 in term of \% annul change.

\begin{tabular}{|c|c|c|c|}
\hline & Historical & Optimistic scenario & Pessimistic scenario \\
\hline & 20182019 & 20202021 & 20202021 \\
\hline $\begin{array}{l}\text { Merchandise trade volume } \\
\text { E xports }\end{array}$ & $2.9-0.1$ & -12.921 .3 & -31.924 .0 \\
\hline North America & 3.81 .0 & -17.123 .7 & -40.919 .3 \\
\hline South and Central America & $0.1-2.2$ & -12.918 .6 & -31.314 .3 \\
\hline Europe & 2.00 .1 & -12.220 .5 & -32.822 .7 \\
\hline Asia & 3.70 .9 & -13.524 .9 & -36.236 .1 \\
\hline Other regions & $0.7-2.9$ & -8.08 .6 & -8.09 .3 \\
\hline Imports & & & \\
\hline North America & $5.2-0.4$ & -14.527 .3 & -33.829 .5 \\
\hline South and Central America & $5.3-2.1$ & -22.223 .2 & -43.819 .5 \\
\hline Europe & 1.50 .5 & -10.319 .9 & -28.924 .5 \\
\hline Asia & $4.9-0.6$ & -11.823 .1 & -31.525 .1 \\
\hline Other regions & 0.31 .5 & -10.013 .6 & -22.618 .0 \\
\hline Real GDP at market exchange rates & 2.92 .3 & -2.57 .4 & -8.85 .9 \\
\hline North America & 2.82 .2 & -3.37 .2 & -9.05 .1 \\
\hline South and Central America & 0.60 .1 & -4.36 .5 & -11.04 .8 \\
\hline Europe & 2.11 .3 & -3.56 .6 & -10.85 .4 \\
\hline Asia & 4.23 .9 & -0.78 .7 & -7.17 .4 \\
\hline Other regions & 2.11 .7 & -1.56 .0 & -6.75 .2 \\
\hline
\end{tabular}

Source: World Trade Organization Secretariat, consensus estimates of historical gross domestic product, GDP projections based on scenarios simulated using the World Trade Organization's global trade model, 2018-2021.

If the pessimistic scenario occurs due to an outbreak of SARS-COV 2, a resurgence of protectionist measures risks slowing down the liberalization of world trade. States will clash severely economically. Undoubtedly, the Nation-States are on the front line on this front, that of globalization to defend their strategic interests and the margins of their respective multinational firms. The image of military war which favors the use of arms to resolve a conflictual situation, that linked to trade aims to submit the other to its will by weakening the competitor, or even reducing his room for maneuver.

Before highlighting the recurrence of these conflicts, it is necessary to explain their characteristics.

\section{Discussions}

It focuses on highlighting the main protagonists and causes of trade disputes. Then some results of the trade wars between China and United States of América are described.

\subsection{List of Sources of Conflict}

Before highlighting the main casus belli, it seems relevant to us to locate the main actors of the disputes [14] first, we will target the distant and immediate causes of trade conflicts. 


\section{The Main Rivals}

It has been established for some time that the United States and Europe dominate the field of the world economy. Some $20 \%$ of the union's exports go to Uncle Sam's country against $19 \%$ of imports from the United States. By projection, the expanding Europe will continue to be a very important commercial area. It is the area that receives the most American goods, services and capital. Transatlantic trade is therefore also the main driver of international trade relations. Despite everything, the Euro-American partnership is the scene of enormous industrial, agricultural, iron and steel conflicts, etc.

But, it was the Americans, most represented at the World Trade Organization, which remain the backbone of conflict.

The United States of America

At the end of the 1990s, the United States [17] reached a level of power that is arguably higher than ever. Certainly, from an economic and monetary point of view, it is not where it was. In 1945, but, from a political and military point of view, this time, no rival arises in the short and medium term, for several decades.

The only power at world level, which would have the resources to play this role, is the European Union. But its construction as an actor is not complete, it has before it an immense work program which will mobilize its energy in the long term (enlargement, deepening, it is the United States' ally in NATO, and above all it has no ambitions of power, in the political-military order). Whatever the sector, military, diplomatic, economic, monetary and financial, commercial, scientific, and technological, normative that one considers, they are at the forefront or close to it. If we try to assess their power in terms of capacities - to do, to make refuse to do, to prevent doing, to do, to harm... - they also have the widest range of possibilities. They have reached a unique, central place in the international system.

This situation could or should herald an inescapable advance over the others.

The observer thinks that Washington, almost saturated with power and having a very comfortable lead, will not only reduce its military effort, to receive the dividends of peace or victory, but also to reconnect with the current that drove it., in the aftermath of the first and second world wars, to work for a better organization of the world, to give more space to multilateralism, international organizations, negotiations, agreements and international law.

But overall, the fear of overtaking the USA has led politicians to integrate trade conflicts into their priorities. Some even point out that the conquest of the foreign market is beginning to take precedence over military and political concerns. Nevertheless, the events of September 11, 2001 will temper this logic since the fight against terrorism has become the top priority of the West and in particular the USA We can say that the question can be less paradoxical than it seems because for the first time in the subconscious of the first world power, the fear of the conspiracy of the Kremlin has given way to other fears, those of plots. Against the welfare of the nation, an expectation of America's divine right to be the richest on this planet.

They believe that international trade is not necessarily the best thing.

This assertion was justified during the tenure of President Bill Clinton through the various appointments. Its Minister of Labor, Robert Reich in 1993, professor at the Kennedy School at Harvard has always said that job creation is a priority. Also, Laura Tyson in 1992 has written extensively on this topic and the lawyer lobbyist (lobbying is a legal activity experienced in defending specific commercial interests, not ideas General on free trade). Many delegates also believe that the trade war should be well prepared like the others because it is a fierce struggle to conquer markets and improve the standard of living in a world where the economy is in great shape. Part a "zero sum ", the advantage of one being often in fact the disadvantage of the other. Their conviction essentially comes down to taking decisions in the direction of strengthening their trade relations in order to avoid any unilateral economic disarmament. This type of reasoning leads to consider the trade gains of other nations as a loss, hence the increasingly frequent demand for better market sharing.

The fact that they are at the heart of trade disputes does not surprise world trade specialists. Whether we like it or not, their dissatisfaction should be put into perspective, even normal, because the least we can add is that a great power can only behave exclusively in this way. After all, is it not the gendarme nation which, in the past, protected the West against the threat of the Communists and which is currently threatened by these same allies who owe it a lot? Before the modeling wave reached its high and murky tide, the Americans left in mute the recriminations against the Japanese firms, considered as unfair by the American specialists. By the way, such a sacrifice was made in the name of the best interests of the nation. At the State and Defense Departments, we were aware that these drawbacks, as unpleasant as they were, were only the partial counterpart of strategic advantages, the anchoring of US bases in Japan, thus saving the place of a naval armada in the harbor of Soviet eastern coasts.

From 1945 until the end of the Cold War, Washington authorized, without looking too closely, Japanese mercantile penetration, which moreover was less virulent than it had become. It was the counterpart of a strategic alliance in Asia dominated by the most populous Communist state in the world, China, but also the former Soviet Union, part of which is Asian, Indonesia, Vietnam, and Korea. North. Today, Americans closely follow the behavior of all trading nations without sparing anybody.

It was undoubtedly in the initiation of this option that the CIA circulated for the first time in 1992 a document on JAPAN 2000, which clearly concludes that Tokyo is pursuing an objective of economic domination. Finally, China's entry into the WTO encourages Americans to follow the same logic.

The European Union

Here the argument aims to say that Europe is the second center of hostilities [8]. Moreover, it is judged by the Yankee 
media as a difficult and tenacious opponent, at least on certain issues. The torch is roughly held by France and Germany, who are trying somehow to resist the American assaults. Overall, France more than any country in Europe, is at the heart of several conflicts of international competition such as agriculture, air transport, even in this area it is helped or supported by other allies. It often intervenes to safeguard the interests of the ACP. More than the two big competitors, that is to say the US and Japan, the European Union finds itself in an uncomfortable negotiating position towards its former colonies. The illustration of such a discourse results from the dispute that took place with the countries of Latin and Central America by favoring the countries of Africa and the Caribbean by import quotas of bananas at privileged prices. Also stimulating the discord between southern European nations and England, in favor of the support quota, and the north, Germany, the most banana consumer in the world, discontented appealed to the legal authorities of the Union.; Disagreement which has repercussions on the solution of other problems which call for unity of action, eroding the common front of trade negotiations vis-à-vis the USA. Another unease of the house of Europe is the trade confrontation with the former Soviet countries which feel they have been duped into the encouragement towards the adoption of capitalism and the law of free markets compared to the benefits they have received.

This divergence is presumed on many subjects, from where a weakening of its power is to be feared. This situation leads to more extra-community concessions, which is undoubtedly appreciated by its rivals. No wonder then that when America and Japan claim and probably believe that united Europe is good for them, too much Europe is inevitably a little worse.

The predictions, like those of Lester Thurow in 1999, who see in the old continent the great future trading bloc evolves periodically based on the perception that one has of its cohesion, perception is of an enlarged Europe or maintaining the status quo. But ineluctably the supporters of the first option will win.

Japan

He appears as an economic giant and a political dwarf [16]. The origin of this situation dates back to the Second World War. It was occupied and militarized. Very quickly, once the peace treaty of September 8, 1951 was concluded, it became by a security treaty of the same day, renewed in 1960 and in 1970, like Germany, the ally of the United States to help contain the Soviet and Chinese push. But the context was different, the alliance was and has remained bilateral; the recovery did not take place in a collective framework, as was the case with Germany's with the communities and NATO. Since its industrial revolution, the Empire of the Rising Sun has continued to scare the global trading blocs because of its strategy of gaining market share.

Its trade balance is very often in surplus. With a few exceptions, it respects free trade (the case of agriculture very closed to foreign competitors).

These main competitors note that the Japanese supremacy
[9-10] is the reflection of protectionism not at its borders but deeply rooted in the behavior of its firms, the result of expansion practices combining both export and installation of assembly subsidiaries or at the same time. Better production, allowing at maturity to eliminate any similar local activity. Sometimes it happens that Japan apologizes for its conquest frenzy, but much more rarely when its scathing aftershocks become recurrent. It prides itself on the free trade argument when its trading partners complain of invasion.

Historically, trade disputes with Japan date back at least to the early 1960s when it was negotiating its accession to the GATT. In 1955, it produced a plan to liberalize his economy after pressure from these Western partners. This external pressure, or gaiatsu, led to a plan that was later adopted by the cabinet to liberalize trade and commerce in 1960.

While Europe had already opened its economy after the Second World War to improve interpenetration, japan also gave a prominent place to exports and imports allowed only with the aim of encouraging suppliers of raw materials for heavy and chemical industries.

However, it was a moderate and limited plan. In this context, it was confronted with public opinion which viewed with a dim view the total opening of borders. Fear of rapid import growth and its direct impact on trade and the balance of payments were feared by the infant steel and automobile industries. Together with lobbyists from the agricultural sector and small medium-sized businesses, they called for the implementation of protective measures. They believed that the opening would lead to job losses and reduced investment. Nowadays, nations are complaining that it is extremely difficult to access the Japanese market.

The problem is essentially on two levels. The first of the difficulties is linked to numerous technical and administrative barriers. The second relates to the structural obstacles that still prevail in the Japanese economic system.

The Americans have therefore included in their trade strategies a reality which can be summed up as follows: wanting to resolve the problem of trade disputes with Japan in a multilateral framework is a lure. This perception of the issue is very much inspired by "Managed Trade" which pursues the conclusion of agreements whose objective is a digital sharing of markets.

Finally, there is a third bloc, admittedly less powerful economically, but which has begun to give voice since the advent of the new GATT.

Developing Countries

There is also a difference in level between developing countries because others are part of the oil cartels and others are part of the least developed countries.

The category of developing countries appeared when the world realized the dimension of the problem of development. This name was preferred to "underdeveloped countries" to avoid being pejorative and also because the dominant trend in the late 1960s and before the oil crisis of the 1970s was optimism. Globally, the international community is unable to find a lasting solution to the development problem.

The least developed countries (LDCs) constitute a sub- 
category within the developing countries: that of the countries which lag the furthest behind.

These categories do not correspond, for the States which are there, to new obligations to be assumed, but on the contrary to rights to be exercised or to benefits to be requested.

Ultimately, we end up with the idea that there should be an advantage for them, recognized by international law, a separate treatment, a duality of standards. This idea has been, at least in part enshrined in international trade law. However, this duality does not mean that there is a break with the principle of sovereign equality. This is absolutely not in question, at the On the contrary, duality aims to allow developing countries to really benefit from it. Various questions, sometimes very delicate, arise in connection with developing countries and subcategories of developing countries: those of the criteria for designating a developing country or a less advanced country; those of knowing whether or not to accept such or such a sub-category.

Often it is states or international aid-providing organizations that determine these categories. Their criteria may not match. The idea of a "least developed countries" category came from the group of 77 and it was the United Nations General Assembly which set the criteria in 1971 (resolution 2768 ([XXVI]).

A more recent category, which testifies to the ineffectiveness of development efforts and the growing severity of the debt problem, is that of the heavily indebted poor countries (HIPCs).

In addition, they have sometimes different, sometimes opposing economic interests (the bananas affair). The multiple attempts at regrouping, those of Nehru in Bandoeng, of the United Nations where they constitute an official group, never went beyond the stage of the political manifesto. The various rounds of the GATT up to the advent of the WTO have demonstrated this state of affairs.

Accentuating the divisions between them, some are commercially helped by the old metropolises to the detriment of others.

The third world covers economies at odds with each other and only shows verbal solidarity because internationally there are some advantages, quotas, more advantageous funding to be derived from the quality of developing countries (differential treatment). Since Singapore 1996, measures have been adopted in favor of the least developed countries, which entail the implementation of special efforts to help them improve their capacity to participate in the multilateral system.

Developed countries have promised to consider how to increase access to their markets for imports from least developed countries and to consider, for example, the possibility of eliminating tariffs entirely. Also, when a dispute concerns one of the least developed countries, the latter may request the Director of the WTO or the Chairman of the Settlement Body to assist the parties in settling the dispute by offering its conciliation and its mediation or by any other means (missions of good offices).
To better understand the future of international trade relations between developed countries and developing countries whose influence will weigh more and more heavily, it should be noted that they are both characterized by fears and hopes.

Fear? Less and less hidden, in itself their development is a good thing, think the rich countries. But, the benefit of one is often the loss of the other in the short term. Hence for years, the Malthusianism imposed on certain categories of exports, such as textiles, strongly hampered by a quota system and the signing of a sort of armistice, the international multifiber agreement (MFA) without which these sales would sweep away all similar activities in America, Europe, and Japan. The second fear results from the maintenance by certain powers of production and export subsidies, thereby slowing down the development of certain sectors in the countries of the South.

Hopes? With the application of preferences for easing the rules of GATT and the new world trade organization. This hope can be nourished if all the recommendations of the agenda of DOHA [22] in 2001 are implemented by the rich countries. This preference is not free since in return they are asked to respect the clauses of intellectual property and free access to their sales of services of all kinds. What do Marxists think about it?

Developed countries can help the poor without upsetting their interests too much. But they create disarray in the name of the great principles of absolute free trade. Principle of course they apply only where the power of those who face them, as in the case of OPEC for oil encourages caution and conciliation.

The rise of international conflicts does not spare them because they have to face future disputes relating to the trade of raw materials.

As an indication, the International Cotton Advisory Council in a study entitled Production and Trade Policies Affecting the Cotton Industry in 2002 concludes that cotton producers in developing countries suffer annual losses of about $\$ 9.5$ billion due to subsidies granted by developed countries. As a result, they must prepare to initiate proceedings with the WTO to request compensation or the outright cancellation of direct aid since cotton occupies an important place in the economy of several African States.

Currently, the member countries of the WTO find it difficult to speak the same language as to the overall physiognomy to be given to international trade, located halfway between liberalism and protectionism. During DOHA Agenda, certain States continued to convey these main criticisms against developed countries.

Also, each other's positions have moved away from the organization's primary objective, that of launching a new round of negotiations. In the meantime, as in the postMarrakech period, international trade did not find the balance desired by the leaders of this institution headed by Mike Moore: trade only served giant firms, exacerbating the imbalance in the volume of trade between the north, rich, and the south, poor and reviving sometimes heated debates 
between the European Union and the United States, in particular around agricultural subsidies. The disagreement remains between these two large blocs. It was transposed to Seattle on the occasion of the WTO ministerial conference in December 1999.

During this meeting, we saw how the Europeans and Americans accused each other, fought over agricultural issues. Developing countries, whether in Africa, Asia, or Latin America are striving to organize themselves to constitute a major force that weighs in the circles of the World Trade Organization? This will did not last because they left in dispersed ranks.

The new organization is led to readjust its operating mechanisms.

It will intervene on a significant commercial volume coming from the China [3], a country whose entry continues to scare many other partners.

\subsection{Remaining and Immediate Causes of Conflicts}

We count the conflicts related to market access, trade defense, anti-competitive practices, and those of geopolitical origins $[12,13]$.

Conflicts Related to Market Access

Access of foreign products to national markets is hampered by tariff and non-tariff barriers. Usually, they relate to customs duties. But the considerable reduction in customs duties since the establishment of the GATT has significantly reduced the weight of tariff barriers in international relations. As a result, these barriers no longer occupy a negligible part in trade.

As for non-tariff barriers, they are public policy measures other than customs duties, the effect of which is to slow down the access of products of foreign origin on a local market. The arsenal of non-tariff protectionist measures is particularly rich and diverse.

Knowledge of international trade shows and makes it possible to identify the means and the most appropriate methods intended to curb imports or create other distortions in international trade. Some international organizations have identified over 20,000 non-tariff barriers.

The most used are: unilateral quantitative restrictions, voluntary export restrictions (VIR), abuse of technical and social standards, administrative harassment.

Conflicts Related to Trade Defense

All countries are used to resorting to economic retaliatory measures (countermeasures to protect themselves against what they consider to be unfair practices or simply to deal with temporary difficulties in a particular sector of activity, which they attribute to imports).

Through chain reactions, these practices could quickly be very damaging to international trade. Hence the need to regulate them. This was done in the GATT 1947 and quite clearly improved by the GATT 1994. There are rules making it possible to deal with unfair business practices, dumping, like those of States, and subsidies. As regards the emergency measures that States may be required to take in the event of market disruption, a specific agreement has been concluded on safeguards.

The Safeguards System

In this regard, it constitutes a safety valve for the viability of multilateralism and as such it is at the very heart of the international trading system. Indeed, it reassures nations by allowing them to take, under certain conditions, urgent protection measures against imports which disrupt their market and which risk causing serious damage to their national production of similar goods. Often, the safeguard measures trigger hostile reactions from the countries which suffer the consequences (the metals affair between the USA and Europe).

To see the extent of the conflicts caused by the safeguard clauses, it suffices to focus on the "hormone beef" affair. It concerned France, which was strict about the quality of the meat, and the US A, which brandished the threat of restrictions on the importation of wine. This is how French wine is frequently in the crosshairs of the American administration. The Food and Drugs Administration conveniently discovered that French wine contained a harmful preservative. Also the "mad cow" affair was interpreted by the English as a measure intended to protect French breeders.

Anti-subsidy (Compensatory) Duties

They designate the special duties that the importing State collects in order to neutralize the effects of subsidies granted, according to it, to the manufacture and export of a product. Its objective is to reestablish the conditions closer to normal competition.

In practice, they are sometimes used as a particularly formidable protectionist weapon. We note that importing countries tend to apply this measure against the most competitive products from the most dynamic countries.

This use is very developed in the USA.

Hence the concept of anti-subsidy rights is therefore directly linked to that of subsidies.

What roles do the public authorities have in supporting investment and production?

This question is not directly related to international trade relations.

On the other hand, the subsidies that the State grants to exports in terms of tax and tariff advantages, preferential export credits, marketing aid, reduction of social charges... constitute one of the main sources of conflicts between trading nations.

Anti-dumping Duties

It consists of exporting products to foreign markets at a price lower than their normal value. The GATT 1947 provided that if this practice caused or threatened to cause material injury to domestic production, the importing State could impose an anti-dumping duty, i.e. the difference between the export price of the product in question and its price on the domestic market of the exporting country at most equal to the dumping margin. The implementation of this provision had been difficult. The system has been improved in the WTO agreements, by the introduction of numerous details, in particular on the very notion of dumping. 
The resurgence of conflicts linked to dumping and antidumping is nowadays one of the characteristics of international trade relations.

Conflicts Related to Anti-competitive Practices

Currency dumping, social dumping, ecological dumping, piracy and counterfeiting, corruption and anti-competitive business practices create significant tensions in international trade relations.

Monetary dumping consists of manipulating the monetary instrument in the service of commercial objectives. This is an old practice. The lack of an international monetary system worthy of the name favors this practice.

The philosophy of the international trading system from its inception was linked to that of Bretton Woods, according to which only a system of fixed parities can ensure the development of the multilateral trading system. The advent of the flexible exchange system of hard currencies has had a considerable impact on the way in which the world economy is regulated.

Since the Jamaica Agreements in 1976, the concerted management of exchange rates has been ensured, above all, by the monetary authorities of the major industrial countries. Also the plazza agreements of September 1985, signed by the finance ministers of the group of five (United States, Great Britain, Federal Republic of Germany, Japan, France), and the Louvre agreements of February 1987 of the G7 organized real cooperation. Between central banks and the treasury departments of the major industrial powers. But this cooperation can hardly replace the Bretton-woods system.

\section{Social Dumping}

It is based on the concept of unfair competition between countries, whose participation in international trade is not accompanied by a comparable development of social conditions. Under this condition, the competitiveness of products from certain emerging countries would only be based on the very low level of labor costs, mainly due to noncompliance with social standards: freedom of association for employers and employees, the right to collective bargaining. Prohibition of child labor, prohibition of forced labor.

Currently the Western powers want to introduce a "social clause"in the multilateral trade system. It aims to take trade action sanctioning violations of employment standards.

Ecological Dumping

Firms that do not integrate ecological costs into their production activities can offer more competitive goods. Arriving on international markets, these goods enter into competition with those manufactured by companies which, for their part, cannot ignore environmental considerations and therefore suffer financial constraints. Strongly denouncing this kind of dumping, certain influential groups are calling for the introduction of an environmental clause in the trading system.

This involves applying trade sanctions to States whose environmental costs have not been integrated into exporting activities. From this perspective, only goods whose production complies with certain ecological criteria could be awarded "eco-labels" allowing them to benefit from the advantages of the international trading system.

Counterfeiting

The increasing opening of borders has also encouraged the development of piracy. It thrives on everything in luxury goods. High-end copies manage to mimic design, weight, label, etc. These plagiarisms are often so perfect that they require a thorough examination by the technicians of the looted brand to discover the fraud. Typically, imitated products trade for between $5 \%$ and $70 \%$ less than the genuine. Rude products come from Asia southeast, those finest from Europe.

It is a crime which consists in infringing the various intellectual property rights. For companies that are victims of counterfeiting, the purchase of a counterfeit product replaces a purchase of the genuine product of the victim company.

It is more serious and dangerous for public health because certain drugs are circulating and sold by certain countries.

Corruption

In international transactions, it hinders competition, distorts trade and harms consumers and taxpayers.

Anti- competitive Business Practices

The field of intervention of the international trading system extends only to interstate relations. It therefore does not cover the practices of private enterprises which, for their part, increasingly call into question the liberalization of trade by erecting private obstacles to replace public tariff and nontariff barriers. The successive waves of mergers and acquisitions and the acceleration of the process of concentration of companies on a universal scale favor the recourse to anti-competitive practices that escape national and regional disciplines. Under these conditions, competition is restricted, prices are increased and markets are divided on the basis of illegal cartels, to the detriment of consumers (captive trade).

Among the anti-competitive practices, intra-firm exchanges occupy a prominent place. Despite their growing weight in international trade, multinational firms essentially escape the rules of international trade.

Indeed, a significant portion of trade (over 30\%) is made up of intra-firm flows between the parent company and its various subsidiaries. Subject to billing and overbilling games, these "intra-firm" flows obey rules very different from the usual principles of supply and demand.

Trade Conflicts of Geopolitical Origin (Boycott and Embargo)

Some conflicts go beyond the commercial sphere proper. The war on pipelines in the Caspian zone or the economic tensions linked to the adoption of extraterritorial laws are of geopolitical origin.

The boycott and the embargo are imposed for generally non-economic reasons.

They are global or partial restrictions on doing business with a country or region of the world. Often presented by those who demand their imposition as essential to make a point of view triumph or to solve a problem, they are rarely effective. At worst, the embargo, if it is effective, is capable of aggravating the conflict. The punished tending to gamble for everything. 


\section{The Recurrence of Sino-American Trade Conflicts as a Symbolic Results}

In recent years, China has become a key player in the game of international trade [6]. The devastating effects of trade wars on the volume of trade affect it as well as its main trading partners, in particular the United States.

Trade wars are declined as rising as tax and customs repeated threats between China and the United States. The Trump presidency (2017-2021), characterized by "America First" has increased the number of trade disputes between the two great powers.

But, long before, the American protectionist arsenal has always existed through Section 301 on intellectual property and Super 301. Originally targeting Japan, Europe, South Korea and Canada, these measures are aimed primarily at China today because the latter has long had surplus trade balances vis-à-vis the States. They authorize the United States President to take retaliatory tariff measures when he judges that competition is unfair. For example, since 2018, the United States has implemented four-year tariffs on Chinese washing machines and solar panels.

China reacted by starting an anti-dumping investigation on American sorghum in order to impose high customs taxes.

Consequently, the trade war generates instabilities causing an escalation of negative reactions: rate increases, use of reprisals and of retaliation.

In the long term, the repetition of these protective measures narrows the volume of trade on the international market and reduces the well-being of end consumers through the drop in the supply of goods and services offered. Today, the total amount of goods subject to tariff increases between these two major partners exceeds $\$ 300$ billion. It should be noted that the sectors affected by the conflicts are diverse and varied: telecommunications, new technologies, automobiles, steel and the issues of American direct investments in China.

It is therefore urgent to regulate these disputes to pacify trade relations and bring free trade to life. At this level, a reform of global governance is required.

\subsection{Results: To Improve Global Governance}

It is rather dispersed through the existence of a few international organizations which evolve in their specialty. The World Trade Organization is the best illustration of the coordinating body and international negotiation [1]. It promotes integral trade that can benefit the entire international community.

Over the decades, several rounds of negotiations have been organized to achieve the gradual elimination of tariffs and trade barriers. The Doha Round held in 2001 is still under negotiation on certain aspects, given the refusal of certain countries to liberalize agricultural trade, and others the refusal to accept industrial competition. Within countries, the group's pressure fiercely defend the barriers that cover.

This situation should always bring back the WTO has encouraged member states to opt for trade negotiations or to submit disputes to its dispute settlement body (DSB).

It appears in many ways as the central element of the multilateral trading system and an original contribution of the WTO to the stability of the world economy. This settlement system is stronger, more automatic and more credible than that of the old GATT. Basically, it is intended as a conciliation mechanism and a means to encourage the settlement of disputes and not just to render judgments.

By participating in the reduction of the implementation of unilateral measures, the mechanism of the settlement body of the World Trade Organization makes a decisive contribution to guaranteeing fair trade for all players in world trade.

\subsection{The Role of Other Institutions}

The United Nations, through its specialized agencies, the United Nations Development Program (UNDP), the World Bank and the International Monetary Fund (IMF) [11], the World Health Organization (WHO) must work in harmony with the " WTO for the coordination of economic, financial and trade policies.

\section{Conclusion}

It is desirable to put the world trade organization [15] back in its place to anticipate and resolve conflicts before they get stuck in time between the great powers. Their perpetuation undoubtedly invokes the resurgence of protectionist measures that are undermining the development of world trade. Unfortunately, the fight against the COVID pandemic, which forces States to close borders, in the short and medium term will induce other trade conflicts since health reasons will be put forward to justify the resurgence of protectionism.

It recommended to promote tariff disarmament to increase the volume of trade, accelerate production and approval of vaccines already produced.

The debate on patent must be conducted in international forums to defeat this pandemic in a raisonable time.

More than ever, it is essential to restore consistency between trade and development $[4,5,18]$. In the end, the existence of an effective mechanism for the settlement of trade wars at the WTO can encourage, by extension, a strengthening of arbitration or institutional cooperation mechanisms in other areas.

\section{References}

[1] Abélès M. (Dir), (2011), "From Antropologists to the WTO: scenes of world governance, CNRS Editions, Paris.

[2] Baldwin R. \& Di Mauro W. B. (2020), "Economic in the COVID Times", CEPR PRESS, London.

[3] Bart D. \& Allen. L. (2014), "Interpretating China as a Regional and Global Power", Palgrave Mac Millan, London.

[4] Boniface P. (2020), "Geopolitics”, Seventh Edition, Eyrolles, Paris. 
[5] Boniface P. (2020), "Geopolitics of the COVID-19", Editions Eyrolles, Paris.

[6] Boylan M. B. \& Mcbeath J. and Wang B. (2021), "US-China relations: Nationalism, the trade war, and COVID-19), Fudan Journal of the Humanities and Social Sciences 14 (1), 23-40.

[7] Defraigne JC. (2019), "The geoeconomic impact of COVID19 on the globalized economy", in Outre-Terre 2019/2 (N ${ }^{\circ}$ 57).

[8] Defraigne JC. \& Nouveau P. (2017), "Introduction to European Union Economy", Deboek, Louvain-la Neuve.

[9] Friedman G. and Lebard M (1991), "The coming war with Japan”, Martin Press, New-York.

[10] George Friedman and Meredith Lebard (1991), the coming war with Japan, Martin Press, New-York.

[11] IMF (2021), "Updated Outlook for the Global Economy".

[12] Globalization and international trade, Cahiers Français $\mathrm{N}^{\circ}$ 325, Paris.

[13] Guilhaudis JF (2017), "Contemporary international relations", Paris, Lexisnexis.
[14] Laidi A. (2010), "States in Economic War", Seuil, Paris.

[15] Lamy P. (2010), "Global Governance in thought and Action", Autrement Edition, Paris.

[16] Laura D. T. (1992), "Trade conflict in high technology industries", Institute for international economics, Washington DC.

[17] Rockoff. H (2012), “America's economic Way of War", Cambridge University Press.

[18] Vedrine H. (2019), "Atlas of Crises and Conflits", Armand Colin, Paris.

[19] World Bank (2020), “Open Data".

[20] World Bank, 2020a "Projected Poverty Impacts of COVID19”, June 19, 2020.

[21] World Bank, 2020b "Potential responses to the COVID-19 outbreak in support of migrants workers", June 19, 2020.

[22] World Trade Organization (2001), "A Trade open to the future", Geneva.

[23] Wordl Trade Outlook (2020). 